Article

\title{
Three New Multiflorane-Type Triterpenes from Pumpkin (Cucurbita maxima) Seeds
}

\author{
Takashi Kikuchi, Mika Takebayashi, Mayumi Shinto, Takeshi Yamada and Reiko Tanaka * \\ Osaka University of Pharmaceutical Sciences, 4-20-1 Nasahara, Takatsuki-shi, Osaka 569-1094, Japan \\ * Author to whom correspondence should be addressed; E-Mail: tanakar@gly.oups.ac.jp; \\ Tel./Fax: +81-72-690-1084.
}

Received: 17 April 2013; in revised form: 9 May 2013 / Accepted: 10 May 2013 /

Published: 14 May 2013

\begin{abstract}
Three new multiflorane-type triterpenes; $7 \alpha$-methoxymultiflor-8-ene-3 $\alpha, 29$-diol 3-acetate-29-benzoate (1), 7-oxomultiflor-8-ene-3 $\alpha, 29$-diol 3-acetate-29-benzoate (2), and multiflora-7,9(11)-diene-3 $\alpha, 29$-diol 3-p-hydroxybenzoate-29-benzoate (3), were isolated from seeds of Cucurbita maxima, along with three known compounds. Compound 3 and multiflora-7,9(11)-diene-3 $\alpha$-29-diol 3-benzoate (5) exhibited potent inhibitory effects on melanogenesis, with low cytotoxicities, and $\mathbf{2}$ exhibited single-digit micromolar cytotoxicity against HL-60 and P388 cells.
\end{abstract}

Keywords: Cucurbita maxima; multiflorane-type triterpenes; melanogenesis inhibitory activity; cytotoxic activity

\section{Introduction}

Pumpkins, including Cucurbita moschata, C. pepo, and C. maxima are gourd squashes of the genus Cucurbita and the family Cucurbitaceae. Cucurbita moschata seeds have been used as an anthelmintic [1], and Cucurbita pepo seeds as an anthelmintic and a diuretic [2].

Cucurbita maxima (English name: squash, pumpkin, Japanese name: kabocha) is indigenous to the plateaus of central and south America, but is cultivated throughout the World. Its fruits, flowers, and seeds have been eaten as vegetables containing vitamins A, C, and E. Several triterpenes such as cucurbita-5,24-dienol [3] and $\alpha$ - and $\beta$-amyrin [4] are present in the seeds of Cucurbita maxima. Additionally, it has been demonstrated that the seeds and flowers of $C$. maxima contain sterols [4-6]. Herein, we report the isolation and structural elucidation of three new multiflorane-type triterpenes 
along with three known compounds, multiflora-7,9(11)-diene-3 $\alpha, 29$-diol 3,29-dibenzoate (4), multiflora7,9(11)-diene-3 $\alpha$-29-diol 3-benzoate (5) and multiflora-5,7,9(11)-triene-3 $\alpha, 29$-diol 3,29-dibenzoate (6), from seeds of $C$. maxima and describe their inhibitory effects on $\alpha-\mathrm{MSH}$-induced melanogenesis in B16 melanomas, and cytotoxic activities against the HL-60 and P388 leukemia cell lines.

\section{Results and Discussion}

Three new multiflorane-type triterpenes 1-3 and three known multiflorane-type triterpenes 4-6 were isolated from the $\mathrm{MeOH}$ extract of $C$. maxima seeds (Figure 1).

Figure 1. Chemical structures of isolated compounds 1-6.
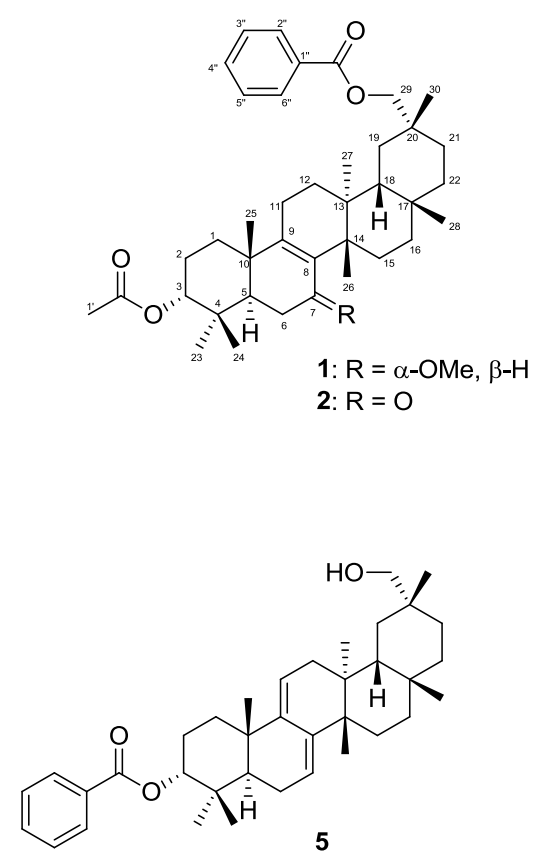
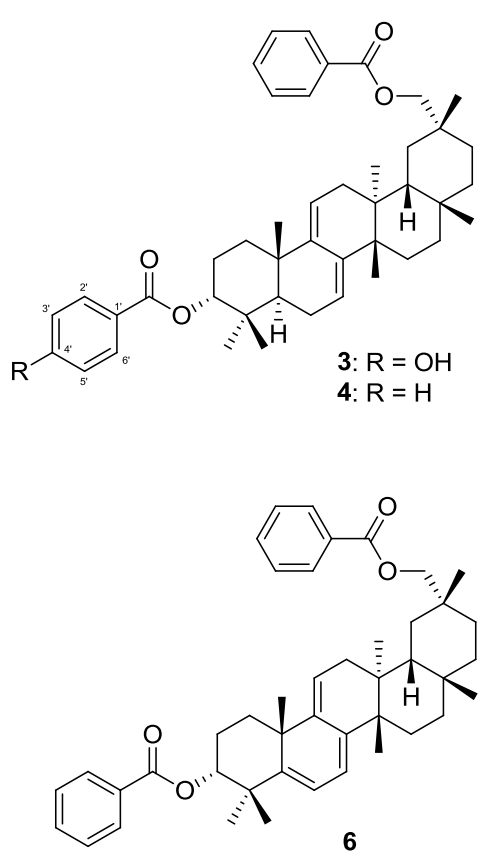

The compound 1 was obtained as an amorphous solid with a molecular ion at $\mathrm{m} / \mathrm{z} 618.4282[\mathrm{M}]^{+}$ (calcd. for $\mathrm{C}_{40} \mathrm{H}_{58} \mathrm{O}_{5}, 618.4285$ ) in the HREIMS. The IR spectrum showed absorptions indicating two carbonyl groups [ $v_{\max } 1743(\mathrm{C}=\mathrm{O}), 1724(\mathrm{C}=\mathrm{O}), 1267(\mathrm{C}-\mathrm{O}), 1247(\mathrm{C}-\mathrm{O}) \mathrm{cm}^{-1}$ ]. The ${ }^{1} \mathrm{H}-$ and ${ }^{13} \mathrm{C}-\mathrm{NMR}$ spectra $\left(\delta_{\mathrm{H}}\right.$ and $\delta_{\mathrm{C}}$ in ppm, Table 1$)$ displayed signals for seven tertiary methyl groups $\left[\delta_{\mathrm{H}} 0.88,0.93\right.$, $0.94,1.04,1.06,1.08,1.13$ (each s)], an oxymethylene [ $\delta_{\mathrm{H}} 4.11,4.15$ (each d); $\left.\delta_{\mathrm{C}} 73.0(\mathrm{t})\right]$, two oxymethines [ $\left.\delta_{\mathrm{H}} 3.53(\mathrm{brs}), 4.68(\mathrm{t}) ; \delta_{\mathrm{C}} 74.0(\mathrm{~d}), 77.2(\mathrm{~d})\right]$, a tetrasubstituted olefin $\left[\delta_{\mathrm{C}} 135.2(\mathrm{~s}), 140.0\right.$ $(\mathrm{s})$ ], an acetoxy group [2.06 (s); $\left.\delta_{\mathrm{C}} 21.5(\mathrm{q}), 171.1(\mathrm{~s})\right]$, a benzoyl group [ $\delta_{\mathrm{H}} 7.46(2 \mathrm{H}, \mathrm{tt}), 7.57(1 \mathrm{H}, \mathrm{tt})$, $8.06(2 \mathrm{H}, \mathrm{dd}) ; \delta_{\mathrm{C}} 128.3(\mathrm{~d}), 129.5(\mathrm{~d}), 130.7$ (s), $132.7(\mathrm{~d}), 166.6(\mathrm{~s})$ ], and a methoxyl group [ $\delta_{\mathrm{H}} 3.24$ (s); 55.0 (q)]. In the HMBC experiment (Figure 2), the following correlations were observed: Me-23 $\left[\delta_{\mathrm{H}} 0.88(\mathrm{~s})\right]$ to C-3 [ $\left.\delta_{\mathrm{c}} 77.2(\mathrm{~d})\right], \mathrm{C}-4, \mathrm{C}-5$, and C-24; Me-24 [ $\left.\delta_{\mathrm{H}} 0.93(\mathrm{~s})\right]$ to C-3, C-4, C-5, and Me-23;

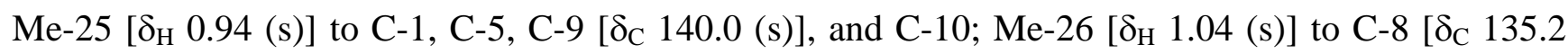
(s)], C-13, C-14, and C-15; Me-27 [ $\delta_{\mathrm{H}} 1.06$ (s)] to C-12, C-13, C-14, and C-18; Me-28 [ $\delta_{\mathrm{H}} 1.13$ (s)] to C-16, C-17, C-18, and C-22; $\mathrm{H}_{2}-29$ [ $\delta_{\mathrm{H}} 4.11,4.15$ (each d)] to C-19, C-20, C-21, C-30, and 29-OCO $\left[\delta_{\mathrm{C}} 166.6(\mathrm{~s})\right] ; \mathrm{Me}-30\left[\delta_{\mathrm{H}} 1.08(\mathrm{~s})\right]$ to $\mathrm{C}-19, \mathrm{C}-20, \mathrm{C}-21$, and C-29 [ $\left.\delta_{\mathrm{C}} 73.0(\mathrm{t})\right] ; \mathrm{H}-3\left[\delta_{\mathrm{H}} 4.68(\mathrm{t})\right]$ to 3-OCO [ $\left.\delta_{\mathrm{C}} 171.1(\mathrm{~s})\right] ; \mathrm{H}-5, \mathrm{H}-6 \beta$, and 7-OMe $\left[\delta_{\mathrm{H}} 3.24(\mathrm{~s})\right]$ to $\mathrm{C}-7$ [ $\left.\delta_{\mathrm{C}} 74.0(\mathrm{~d})\right] ; \mathrm{H}-6 \beta, \mathrm{H}-11$, and Me-26 to C-8 [ $\left.\delta_{\mathrm{C}} 135.2(\mathrm{~s})\right]$; and H-11 and Me-25 to C-9 [ $\delta_{\mathrm{C}} 140.0$ (s)] (Figure 2). 
Table 1. ${ }^{1} \mathrm{H}(500 \mathrm{MHz})$ and ${ }^{13} \mathrm{C}(125 \mathrm{MHz})$ NMR spectroscopic data of compounds $\mathbf{1}-\mathbf{3}\left(\mathrm{CDCl}_{3}\right){ }^{\mathrm{a}}$.

\begin{tabular}{|c|c|c|c|c|c|c|}
\hline \multirow{2}{*}{ Position } & \multicolumn{2}{|r|}{1} & \multicolumn{2}{|r|}{2} & \multicolumn{2}{|r|}{3} \\
\hline & $\delta_{\mathrm{C}}(\mathrm{ppm})$, type & $\delta_{\mathrm{H}}(\mathrm{ppm})(J$ in $\mathrm{Hz})$ & $\delta_{\mathrm{C}}($ ppm), type & $\delta_{\mathrm{H}}(\mathrm{ppm})(J$ in $\mathrm{Hz})$ & $\delta_{\mathrm{C}}($ ppm), type & $\delta_{\mathrm{H}}(\mathrm{ppm})(J$ in $\mathrm{Hz})$ \\
\hline 1 & $29.7, \mathrm{t}$ & $\begin{array}{l}\alpha, 1.39, \mathrm{~m} \\
\beta, 1.45, \mathrm{~m}\end{array}$ & $29.5, \mathrm{t}$ & $1.59, \mathrm{~m}$ & $31.8, \mathrm{t}$ & $\begin{array}{l}\alpha, 1.97, \mathrm{~m} \\
\beta, 1.58, \mathrm{~m}\end{array}$ \\
\hline 2 & $23.4, \mathrm{t}$ & $\begin{array}{l}\alpha, 1.64, \mathrm{~m} \\
\beta, 1.85, \mathrm{~m}\end{array}$ & $22.9, \mathrm{t}$ & $\begin{array}{l}\alpha, 1.75, \mathrm{~m} \\
\beta, 1.95, \mathrm{~m}\end{array}$ & $23.1, \mathrm{t}$ & $\begin{array}{l}\alpha, 1.87, \mathrm{~m} \\
\beta, 1.98, \mathrm{~m}\end{array}$ \\
\hline 3 & $77.2, \mathrm{~d}$ & $4.68, \mathrm{t}(2.8)$ & $76.9, \mathrm{~d}$ & $4.71, \mathrm{t}(2.5)$ & $78.8, \mathrm{~d}$ & 4.82, brd (3.2) \\
\hline 4 & $36.2, \mathrm{~s}$ & & $36.5, \mathrm{~s}$ & & $37.6, \mathrm{~s}$ & \\
\hline 5 & $39.7, \mathrm{~d}$ & $1.99, \mathrm{dd}(12.5,1.1)$ & $42.6, d$ & 2.07, dd $(7.5,3.9)$ & $43.9, \mathrm{~d}$ & $1.94, \mathrm{~m}$ \\
\hline 6 & $22.4, \mathrm{t}$ & $\begin{array}{l}\alpha, 1.89, \mathrm{~m} \\
\beta, 1.30, \mathrm{~m}\end{array}$ & $36.2, \mathrm{t}$ & $2.35, \mathrm{~m}$ & $23.7, \mathrm{t}$ & $\begin{array}{l}\alpha, 2.14, \text { brt (5.0) } \\
\beta, 2.08, \mathrm{~m}\end{array}$ \\
\hline 7 & $74.0, \mathrm{~d}$ & 3.53 , brs & $198.3, \mathrm{~s}$ & & $119.4, \mathrm{~d}$ & 5.60, brd (5.9) \\
\hline 8 & $135.2, \mathrm{~s}$ & & $142.5, \mathrm{~s}$ & & $142.3, \mathrm{~s}$ & \\
\hline 9 & $140.0, \mathrm{~s}$ & & 163.3, s & & $145.8, \mathrm{~s}$ & \\
\hline 10 & $38.5, \mathrm{~s}$ & & $39.2, \mathrm{~s}$ & & $36.4, \mathrm{~s}$ & \\
\hline 11 & $21.0, \mathrm{t}$ & $1.95,2 \mathrm{H}, \mathrm{m}$ & $22.2, \mathrm{t}$ & $\begin{array}{l}\alpha, 2.30, \mathrm{~m} \\
\beta, 2.14, \mathrm{~m}\end{array}$ & $114.8, \mathrm{~d}$ & 5.29, brd (5.9) \\
\hline 12 & $31.2, \mathrm{t}$ & $\begin{array}{l}\alpha, 1.34, \mathrm{~m} \\
\beta, 1.60, \mathrm{~m}\end{array}$ & $29.8, \mathrm{t}$ & $\begin{array}{l}\alpha, 1.38, \mathrm{~m} \\
\beta, 1.59, \mathrm{~m}\end{array}$ & $39.1, \mathrm{t}$ & $\begin{array}{l}\alpha, 2.08, \mathrm{~m} \\
\beta, 1.79, \mathrm{~m}\end{array}$ \\
\hline $\begin{array}{l}13 \\
14\end{array}$ & $\begin{array}{l}37.0, \mathrm{~s} \\
41.7 \mathrm{~s}\end{array}$ & & $\begin{array}{l}38.0, \mathrm{~s} \\
39.1 \mathrm{~s}\end{array}$ & & $\begin{array}{l}37.5, \mathrm{~s} \\
40.4 . \mathrm{s}\end{array}$ & \\
\hline 15 & $25.4, \mathrm{t}$ & $\begin{array}{l}\alpha, 2.18, \mathrm{~m} \\
\beta, 1.25, \mathrm{~m}\end{array}$ & $29.4, \mathrm{t}$ & $\begin{array}{l}\alpha, 2.43, \mathrm{~m} \\
\beta, 1.59, \mathrm{~m}\end{array}$ & $27.6, \mathrm{t}$ & $\begin{array}{l}\alpha, 1.63, \mathrm{~m} \\
\beta, 1.42, \mathrm{~m}\end{array}$ \\
\hline 16 & $36.9, \mathrm{t}$ & $1.56,2 \mathrm{H}, \mathrm{m}$ & $35.9, \mathrm{t}$ & $\begin{array}{l}\alpha, 1.39, \mathrm{~m} \\
\beta, 1.63, \mathrm{~m}\end{array}$ & $37.2, \mathrm{t}$ & $\begin{array}{l}\alpha, 1.76, \mathrm{~m} \\
\beta, 1.49, \mathrm{~m}\end{array}$ \\
\hline 17 & $31.1, \mathrm{~s}$ & & $31.1, \mathrm{~s}$ & & $31.9, \mathrm{~s}$ & \\
\hline 18 & $44.0, \mathrm{~d}$ & $1.59, \mathrm{~m}$ & $41.3, \mathrm{~d}$ & $1.66, \mathrm{~m}$ & $45.1, d$ & $1.68, \mathrm{~m}$ \\
\hline 19 & $28.8, \mathrm{t}$ & $\begin{array}{l}\alpha, 1.84, \mathrm{~m} \\
\beta, 1.30, \mathrm{~m}\end{array}$ & $30.2, \mathrm{t}$ & $\begin{array}{l}\alpha, 1.63, \mathrm{~m} \\
\beta, 1.29, \mathrm{dd}(15.7,3.9)\end{array}$ & $29.6, \mathrm{t}$ & $\begin{array}{l}\alpha, 1.76, \mathrm{~m} \\
\beta, 1.30, \mathrm{~m}\end{array}$ \\
\hline
\end{tabular}


Table 1. Cont

\begin{tabular}{|c|c|c|c|c|c|c|}
\hline \multirow{2}{*}{ Position } & \multicolumn{2}{|r|}{1} & \multicolumn{2}{|r|}{2} & \multicolumn{2}{|r|}{3} \\
\hline & $\delta_{\mathrm{C}}(\mathrm{ppm})$, type & $\delta_{\mathrm{H}}(\mathrm{ppm})(J$ in $\mathrm{Hz})$ & $\delta_{\mathrm{C}}(\mathrm{ppm})$, type & $\delta_{\mathrm{H}}(\mathrm{ppm})(J$ in $\mathrm{Hz})$ & $\delta_{\mathrm{C}}(\mathrm{ppm})$, type & $\delta_{\mathrm{H}}(\mathrm{ppm})(J$ in $\mathrm{Hz})$ \\
\hline 20 & $31.9, \mathrm{~s}$ & & $32.4, \mathrm{~s}$ & & $29.9, \mathrm{~s}$ & \\
\hline 21 & $29.5, \mathrm{t}$ & $1.51,2 \mathrm{H}, \mathrm{m}$ & $28.3, \mathrm{t}$ & $\begin{array}{l}\alpha, 1.56, \mathrm{~m} \\
\beta, 1.47 . \mathrm{m}\end{array}$ & $30.1, \mathrm{t}$ & $1.63,2 \mathrm{H}, \mathrm{m}$ \\
\hline 22 & $35.7, \mathrm{t}$ & $\begin{array}{l}\alpha, 1.79, \mathrm{~m} \\
\beta, 0.97, \mathrm{~m}\end{array}$ & $38.5, \mathrm{t}$ & $\begin{array}{l}\alpha, 1.50, \mathrm{~m} \\
\beta, 1.03, \mathrm{~m}\end{array}$ & $33.0, \mathrm{t}$ & $\begin{array}{l}\alpha, 1.89, \mathrm{~m} \\
\beta, 0.95, \mathrm{~m}\end{array}$ \\
\hline 23 & $27.2, \mathrm{q}$ & $0.88, \mathrm{~s}$ & $26.7, \mathrm{q}$ & $0.87, \mathrm{~s}$ & $28.0, \mathrm{q}$ & $0.90, \mathrm{~s}$ \\
\hline 24 & $22.3, \mathrm{q}$ & $0.93, \mathrm{~s}$ & $21.4, \mathrm{q}$ & $0.99, \mathrm{~s}$ & $21.6, \mathrm{q}$ & $1.03, \mathrm{~s}$ \\
\hline 25 & $18.2, \mathrm{q}$ & $0.94, \mathrm{~s}$ & $18.0, \mathrm{q}$ & $1.03, \mathrm{~s}$ & $21.1, \mathrm{q}$ & $1.01, \mathrm{~s}$ \\
\hline 26 & $26.1, \mathrm{q}$ & $1.04, \mathrm{~s}$ & $26.7, \mathrm{q}$ & $1.39, \mathrm{~s}$ & $21.2, \mathrm{q}$ & $0.94, \mathrm{~s}$ \\
\hline 27 & $18.9, \mathrm{q}$ & $1.06, \mathrm{~s}$ & $18.3, \mathrm{q}$ & $0.99, \mathrm{~s}$ & $19.9, \mathrm{q}$ & $1.03, \mathrm{~s}$ \\
\hline 28 & $31.2, \mathrm{q}$ & $1.13, \mathrm{~s}$ & $30.6, q$ & $1.22, \mathrm{~s}$ & $31.4, \mathrm{q}$ & $1.11, \mathrm{~s}$ \\
\hline 29 & $73.0, \mathrm{t}$ & $\begin{array}{l}\text { a, 4.15, d (10.8) } \\
\text { b, 4.09, d (10.8) }\end{array}$ & $75.0, \mathrm{t}$ & $\begin{array}{l}\text { a, 4.05, d (10.5) } \\
\text { b, 4.02, d (10.5) }\end{array}$ & $74.2, \mathrm{t}$ & $\begin{array}{l}\text { a, 4.34, d (10.7) } \\
\text { b, 4.12, d (10.7) }\end{array}$ \\
\hline 30 & $29.7, \mathrm{q}$ & $1.08, \mathrm{~s}$ & $26.5, \mathrm{q}$ & $1.15, \mathrm{~s}$ & $31.3, \mathrm{q}$ & $1.16, \mathrm{~s}$ \\
\hline 3-OCEO & $171.1, \mathrm{~s}$ & & $170.6, \mathrm{~s}$ & & $165.4, \mathrm{~s}$ & \\
\hline $1^{\bar{\prime}}$ & $21.5, \mathrm{q}$ & $2.06, \mathrm{~s}$ & $21.3, \mathrm{q}$ & $2.07, \mathrm{~s}$ & 123.1, s & \\
\hline $2^{\prime}, 6^{\prime}$ & & & & & 131.9, d & $7.85,2 \mathrm{H}, \mathrm{dd}(8.4,2.8)$ \\
\hline $3^{\prime}, 5^{\prime}$ & & & & & $115.3, \mathrm{~d}$ & $6.84,2 \mathrm{H}, \mathrm{dd}(8.4,2.8)$ \\
\hline $4^{\prime}$ & & & & & $160.8, \mathrm{~s}$ & \\
\hline 29-OCEO & $166.6, \mathrm{~s}$ & & $166.8, \mathrm{~s}$ & & $168.5, \mathrm{~s}$ & \\
\hline $1 "$ & $130.7, \mathrm{~s}$ & & $130.6, \mathrm{~s}$ & & $130.2, \mathrm{~s}$ & \\
\hline 2", 6" & $129.5, \mathrm{~d}$ & $8.06,2 \mathrm{H}, \mathrm{dd}(7.4,1.3)$ & $129.5, \mathrm{~d}$ & $8.06,2 \mathrm{H}, \mathrm{dd}(8.0,1.4)$ & 129.6, d & $8.04,2 \mathrm{H}, \mathrm{dd}(7.4,1.4)$ \\
\hline $3^{\prime \prime}, 5^{\prime \prime}$ & $128.3, \mathrm{~d}$ & $7.46,2 \mathrm{H}, \mathrm{tt}(7.4,1.3)$ & $132.8, \mathrm{~d}$ & $7.46,2 \mathrm{H}, \mathrm{tt}(8.0,1.4)$ & $128.8, \mathrm{~d}$ & $7.46,2 \mathrm{H}, \mathrm{tt}(7.4,1.4)$ \\
\hline 4" & $132.7, \mathrm{~d}$ & $7.57, \mathrm{tt}(7.4,1.3)$ & $128.4, \mathrm{~d}$ & $7.58, \mathrm{tt}(8.0,1.4)$ & 133.6, d & $7.56, \mathrm{tt}(7.4,1.4)$ \\
\hline $\begin{array}{l}\text { 7-OMe } \\
4^{\prime}-\mathrm{OH}\end{array}$ & $55.0, \mathrm{q}$ & $3.24, \mathrm{~s}$ & & & & 7.49, brs \\
\hline
\end{tabular}

${ }^{a}$ Assignments were based on ${ }^{1} \mathrm{H}^{-1} \mathrm{H}$ COSY, HMQC, HMBC and NOESY spectroscopic data. 
Figure 2. Key $\mathrm{HMBC}(\longrightarrow)$ and ${ }^{1} \mathrm{H}^{1}{ }^{1} \mathrm{H} \operatorname{COSY}(\longrightarrow)$ correlations of $\mathbf{1}$.

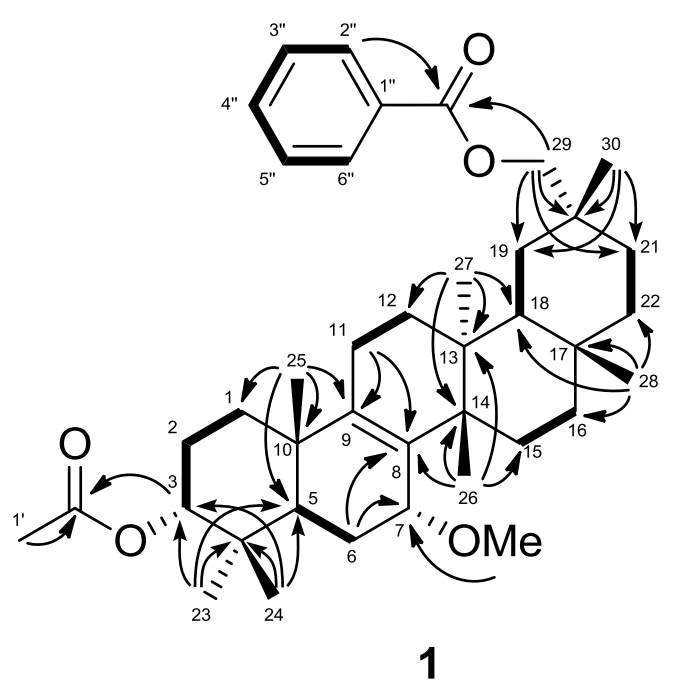

In the ${ }^{1} \mathrm{H}-{ }^{1} \mathrm{H}$ COSY experiment, $\mathrm{H}-7\left[\delta_{\mathrm{H}} 3.53\right.$ (brs)] correlated with $\mathrm{H}_{2}-6\left[\delta_{\mathrm{H}} 1.30,1.89\right]$. The following significant NOE interactions were observed in 1: H-5/H-15 $\alpha$; $-15 \alpha / \mathrm{Me}-27 ; \mathrm{Me}-27 / \mathrm{H}_{2}-29$; Me-26/H-7, Me-25, and H-18; H-18/Me-28 (Figure 3). Therefore, the methoxy group at C-7 had the $\alpha$ (axial)-orientation. The configuration of the acetoxy group at $\mathrm{C}-3$ was established as the $\alpha$ (axial)-orientation due to the NOE correlations between $\mathrm{H}-3$ and Me-23 and Me-24, and the coupling constants of $\mathrm{H}-3\left[\delta_{\mathrm{H}} 4.68\left(\mathrm{t}, J_{3 \beta .2 \alpha ; 3 \beta, 2 \beta}=2.8 \mathrm{~Hz}\right)\right]$. Therefore, 1 was determined as $7 \alpha$-methoxymultiflor-8-ene-3 $\alpha, 29$-diol 3-acetate-29-benzoate.

Figure 3. Key NOE $(\longleftrightarrow$ ) correlations of $\mathbf{1}$.

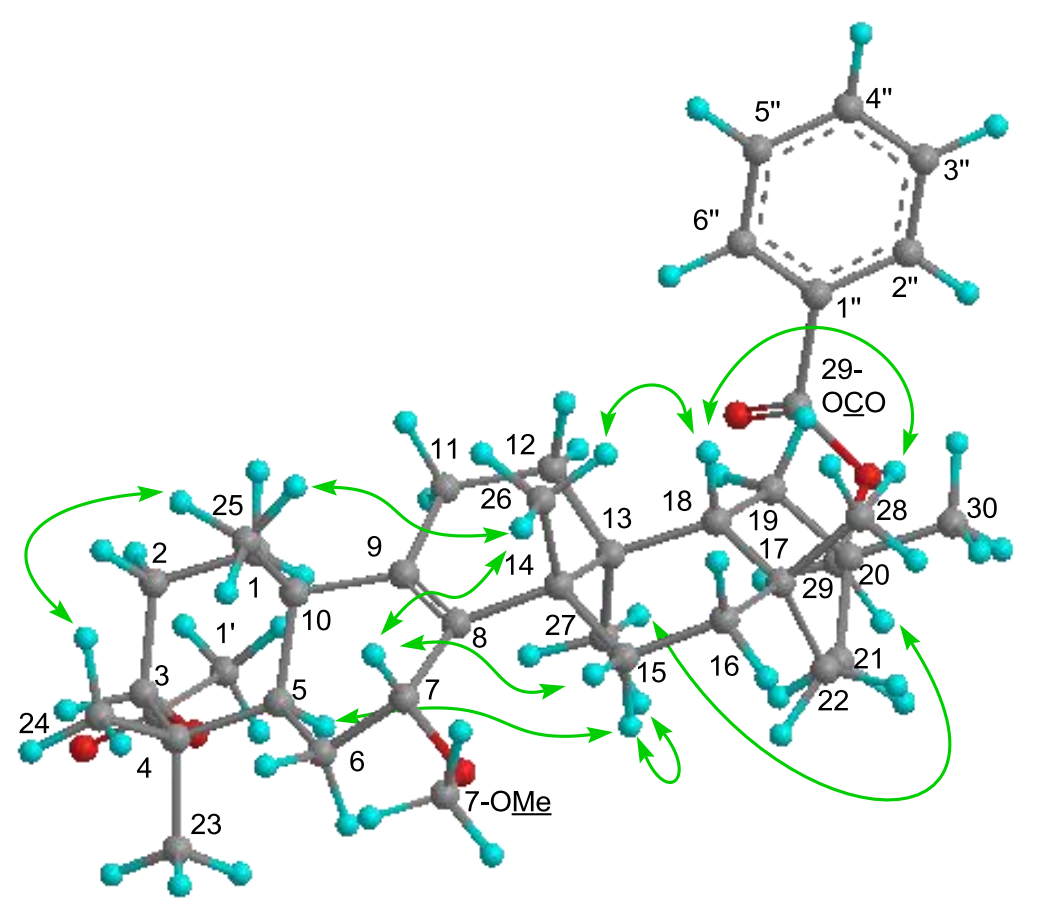

Compound 2 exhibited a $[\mathrm{M}]^{+}$ion in the HREIMS data at $\mathrm{m} / \mathrm{z} 602.3975$ whose molecular formula was $\mathrm{C}_{39} \mathrm{H}_{54} \mathrm{O}_{5}$ (calcd. 602.3972). The IR and UV spectra showed absorptions indicating two carbonyl 
groups $\left[v_{\max } 1739(\mathrm{C}=\mathrm{O}), 1723(\mathrm{C}=\mathrm{O}), 1270(\mathrm{C}-\mathrm{O}), 1245(\mathrm{C}-\mathrm{O}) \mathrm{cm}^{-1}\right.$ ] and an $\alpha, \beta$-unsaturated six-membered ring ketone $\left[\nu_{\max } 1658 \mathrm{~cm}^{-1} ; \lambda_{\max } 233.0 \mathrm{~nm}(\log \varepsilon 3.91)\right] .2$ is similar to 1 according to the ${ }^{1} \mathrm{H}$ - and ${ }^{13} \mathrm{C}-\mathrm{NMR}$ spectra $\left(\delta_{\mathrm{H}}\right.$ and $\delta_{\mathrm{C}}$ in ppm). In the $\mathrm{HMBC}$ experiment, cross-peaks were observed from H-5 and H-6 to C-7 [ $\delta_{\mathrm{C}} 198.3$ (s)]; and from $\mathrm{H}_{2}-11$ to C-8 [ $\delta_{\mathrm{C}} 142.5$ (s)] and C-9 [ $\delta_{\mathrm{C}} 163.3$ (s)] (Figure 4). In the ${ }^{1} \mathrm{H}-{ }^{1} \mathrm{H}$ COSY experiment, $\mathrm{H}_{2}-11\left[\delta_{\mathrm{H}} 2.14,2.30\right]$ correlated with $\mathrm{H}_{2}-12$ $\left[\delta_{\mathrm{H}} 1.38,1.59\right]$, but $\mathrm{H}_{2}-6\left[\delta_{\mathrm{H}} 2.35(2 \mathrm{H})\right]$ correlated with only $\mathrm{H}-5$ [ $\left.\delta_{\mathrm{H}} 2.07(\mathrm{dd})\right]$ (Figure 4). NOESY experiments revealed that the relative of $\mathbf{2}$ to have the same conformation as $\mathbf{1}$. As a result, $\mathbf{2}$ was determined to be 7-oxomultiflor-8-ene-3 $\alpha, 29$-diol 3-acetate-29-benzoate.

Figure 4. Key $\mathrm{HMBC}(\longrightarrow)$ and ${ }^{1} \mathrm{H}^{1}{ }^{1} \mathrm{H} \operatorname{COSY}(\longrightarrow)$ correlations of 2.

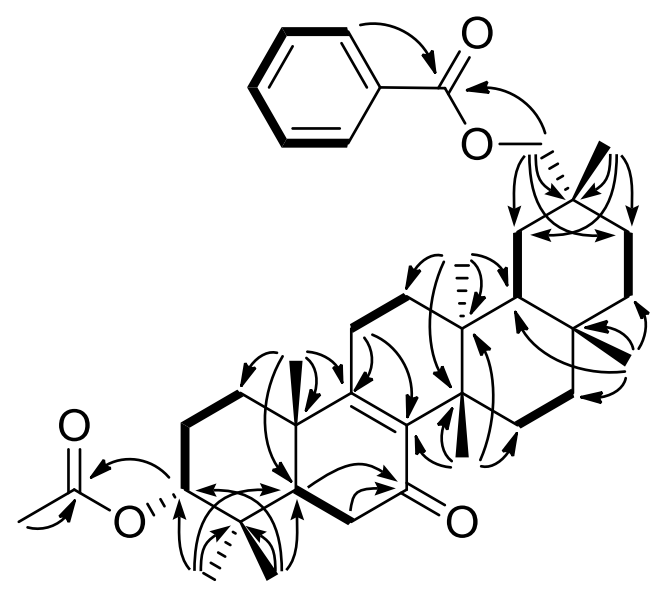

2

The molecular formula of 3 was determined as $\mathrm{C}_{44} \mathrm{H}_{56} \mathrm{O}_{5}$ based on the HREIMS $(\mathrm{m} / \mathrm{z}, 664.4127$, calcd. 664.4127). In addition, $m / z 526\left[\mathrm{M}-\mathrm{C}_{7} \mathrm{H}_{6} \mathrm{O}_{3}\right]^{+}$indicated the presence of a hydroxybenzoyloxy group. The IR spectrum showed the existence of a hydroxy group $\left(v_{\max } 3436 \mathrm{~cm}^{-1}\right)$ and aryl esters $\left(v_{\max } 1716,1683,1509,1456,1274 \mathrm{~cm}^{-1}\right)$. The ${ }^{1} \mathrm{H}$ - and ${ }^{13} \mathrm{C}$ NMR spectra of $\mathbf{3}$ displayed signals for seven tertiary methyl groups $\left[\delta_{\mathrm{H}} 0.90,0.94,1.01,1.03(6 \mathrm{H}), 1.11,1.16\right.$ (each s)], an oxymethylene $\left[\delta_{\mathrm{H}}\right.$ $4.12,4.34$ (each d); $\left.\delta_{\mathrm{C}} 74.2(\mathrm{t})\right]$, an oxymethine [ $\left.\delta_{\mathrm{H}} 4.82(\mathrm{brd}) ; \delta_{\mathrm{C}} 78.8(\mathrm{~d})\right]$, a heteroannular diene [ $\delta_{\mathrm{H}}$ 5.29, 5.60 (each brd); $\left.\delta_{\mathrm{C}} 114.8(\mathrm{~d}), 119.4(\mathrm{~d}), 142.3(\mathrm{~s}), 145.8(\mathrm{~s})\right]$, two aryl ester groups [ $\delta_{\mathrm{H}} 6.84(\mathrm{dd})$, $7.46(\mathrm{tt}), 7.56(\mathrm{tt}), 7.85(\mathrm{dd}), 8.04(\mathrm{dd}) ; \delta_{\mathrm{C}} 115.3(\mathrm{~d}), 123.1(\mathrm{~s}), 128.8(\mathrm{~d}), 129.6(\mathrm{~d}), 130.2(\mathrm{~s}), 131.9$ (d), $133.6(\mathrm{~d}), 160.8(\mathrm{~s}), 165.4(\mathrm{~s}), 168.5(\mathrm{~s})]$, and a hydroxyl group [ $\delta_{\mathrm{H}} 7.49$ (brs)]. The ${ }^{1} \mathrm{H}$ and ${ }^{13} \mathrm{C}$-NMR spectra of 3 were similar to those of multiflora-7,9(11)-diene-3 $\alpha$-29-diol 3,29-dibenzoate (4) except for the signal of the C-4' [ $\delta_{\mathrm{C}} 160.8(\mathrm{~s})$ in $3, \delta_{\mathrm{C}} 133.6(\mathrm{~s})$ in 4$]$. In the HMBC experiment, the correlations were observed from 4'-Oㅍ $\left[\delta_{\mathrm{H}} 7.49\right.$ (brs)] to C-4' (Figure 5). Therefore the structure of 3 was determined to be multiflora-7,9(11)-diene-3 $\alpha, 29$-diol 3-p-hydroxybenzoate-29-benzoate.

The known compounds 4 [7,8] and 5 [9] were identified by comparing MS and ${ }^{1} \mathrm{H}$ and ${ }^{13} \mathrm{C}-\mathrm{NMR}$ data with published data, and 6 [7] by MS and ${ }^{1} \mathrm{H}$ NMR data. 
Figure 5. Key $\mathrm{HMBC}(\longrightarrow)$ and ${ }^{1} \mathrm{H}^{1}{ }^{1} \mathrm{H}$ COSY $(\longrightarrow)$ correlations of 3.

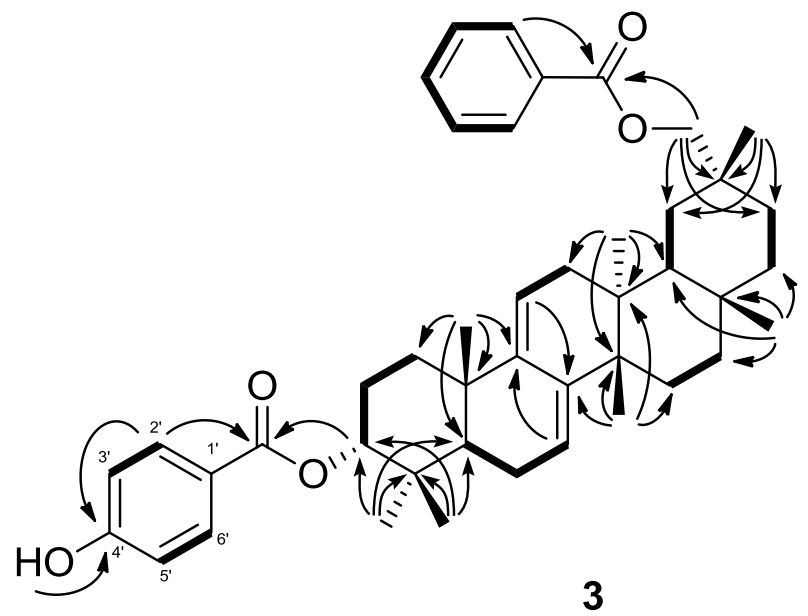

The six multiflorane triterpenes 1-6 from $C$. maxima were evaluated for inhibitory activities against $\alpha$-MSH-induced melanogenesis in B16 melanomas (Table 2). At a low concentration $(10 \mu \mathrm{M}), 5$ inhibited melanogenesis ( $76.9 \%$ of melanin content) with low cytotoxicity ( $99.5 \%$ of cell viability). 5 also inhibited melanogenesis ( $70.9 \%$ of melanin content) with low cytotoxicity ( $97.7 \%$ cell viability) at $30 \mu \mathrm{M}$. At a high concentration $(100 \mu \mathrm{M}), \mathbf{3}$ and $\mathbf{5}$ exhibited inhibitory activities $(51.8$ and $67.4 \%$ of melanin content, respectively) with low cytotoxicity (95.1 and $99.6 \%$ of cell viability, respectively). The activity levels of compounds 5 at 10 and $30 \mu \mathrm{M}$ were comparable with or superior to those of the positive control, arbutin, which has been recognized as a useful depigmentation compound for skin whitening in the cosmetic industry [10]. It appears that two multiflorane-type triterpenes, 5 from C. maxima seeds, may be valuable as potential skin-whitening agents. The melanogenesis inhibitory activity of $2(28.1 \%$ of melanin content at $100 \mu \mathrm{M})$ is thought to be due to their cytotoxic action (69.0\% of cell viability at $100 \mu \mathrm{M})$.

Table 2. Melanogenesis inhibitory activity and cytotoxicity in B16 mouse melanoma cells of multiflorane-type triterpenes isolated from Cucurbita maxima seeds ${ }^{\text {a }}$.

\begin{tabular}{|c|c|c|c|c|c|c|}
\hline \multirow[b]{2}{*}{ Compound } & \multicolumn{2}{|c|}{ mean \pm S.D. $(\%)$ at $10 \mu M$} & \multicolumn{2}{|c|}{ mean \pm S.D. $(\%)$ at $30 \mu M$} & \multicolumn{2}{|c|}{ mean \pm S.D. $(\%)$ at $100 \mu \mathrm{M}$} \\
\hline & $\begin{array}{c}\text { Melanin } \\
\text { content }\end{array}$ & $\begin{array}{c}\text { Cell } \\
\text { viability }\end{array}$ & $\begin{array}{c}\text { Melanin } \\
\text { content }\end{array}$ & $\begin{array}{c}\text { Cell } \\
\text { viability }\end{array}$ & $\begin{array}{c}\text { Melanin } \\
\text { content }\end{array}$ & $\begin{array}{c}\text { Cell } \\
\text { viability }\end{array}$ \\
\hline 1 & $94.8 \pm 0.5$ & $92.7 \pm 2.2$ & $77.1 \pm 3.8$ & $84.4 \pm 4.0$ & $73.7 \pm 3.6$ & $84.3 \pm 5.2$ \\
\hline 2 & $106.8 \pm 9.3$ & $106.3 \pm 8.0$ & $92.2 \pm 5.4$ & $107.1 \pm 7.4$ & $28.1 \pm 2.3$ & $69.0 \pm 4.5$ \\
\hline 3 & $91.2 \pm 2.2$ & $107.2 \pm 5.1$ & $81.8 \pm 4.0$ & $105.6 \pm 3.1$ & $51.8 \pm 8.0$ & $95.1 \pm 4.3$ \\
\hline 4 & $98.4 \pm 3.2$ & $110.8 \pm 4.3$ & $102.2 \pm 11.7$ & $103.0 \pm 8.2$ & $95.4 \pm 8.4$ & $101.1 \pm 5.9$ \\
\hline 5 & $76.9 \pm 4.0$ & $99.5 \pm 3.3$ & $70.9 \pm 0.1$ & $97.7 \pm 3.1$ & $67.4 \pm 3.6$ & $99.6 \pm 2.0$ \\
\hline 6 & $107.8 \pm 2.6$ & $91.0 \pm 1.6$ & $111.8 \pm 7.1$ & $81.8 \pm 2.1$ & $82.0 \pm 5.1$ & $74.4 \pm 3.2$ \\
\hline $\operatorname{arbutin}^{\mathrm{b}}$ & $88.9 \pm 2.3$ & $100.0 \pm 2.7$ & $72.3 \pm 3.1$ & $94.4 \pm 1.2$ & $55.3 \pm 1.0$ & $89.9 \pm 0.3$ \\
\hline
\end{tabular}

${ }^{\mathrm{a}}$ Melanin content $(\%)$ and cell viability (\%) were determined based on the absorbance at $450 \mathrm{~nm}$, and $540 \mathrm{~nm}$, respectively, by comparison with values for DMSO (100\%). Each value represents the mean \pm standard deviation (S.D.) of three determinations. The concentration of DMSO in the sample solution was $2 \mu \mathrm{L} / \mathrm{mL}$.

${ }^{\mathrm{b}}$ Reference compound. 
Six triterpenes and a reference compound, 5-fluorouracil (5-FU), were also evaluated for cytotoxic activities against human leukemia (HL-60) and murine leukemia (P388) cell lines by means of the MTT assay (Table 3). Compound 2 exhibited single-digit micromolar cytotoxicity with $\mathrm{IC}_{50}$ values of 7.0 and $9.5 \mu \mathrm{M}$ against HL-60 and P388 cells, respectively. It was slightly less cytotoxic than 5-FU [IC 50.3 (HL-60); 1.9 (P388) $\mu \mathrm{M}]$ (Table 3).

Table 3. Cytotoxic activities of multiflorane-type triterpenes from Cucurbita maxima seeds.

\begin{tabular}{|c|c|c|}
\hline \multirow[b]{2}{*}{ Compound } & \multicolumn{2}{|c|}{$\mathrm{IC}_{50}(\mu \mathrm{M})^{\mathrm{a}}$} \\
\hline & $\begin{array}{c}\text { HL-60 } \\
\text { (human leukemia) }\end{array}$ & $\begin{array}{c}\text { P388 } \\
\text { (murine leukemia) }\end{array}$ \\
\hline 1 & $>100$ & $>100$ \\
\hline 2 & $7.0 \pm 1.1$ & $9.5 \pm 1.1$ \\
\hline 3 & $55.9 \pm 1.1$ & $92.6 \pm 1.3$ \\
\hline 4 & $>100$ & $>100$ \\
\hline 5 & $>100$ & $>100$ \\
\hline 6 & $54.1 \pm 1.3$ & $46.7 \pm 1.2$ \\
\hline 5-fluorouracil ${ }^{\mathrm{b}}$ & $2.3 \pm 0.2$ & $1.9 \pm 0.2$ \\
\hline
\end{tabular}

\footnotetext{
${ }^{\mathrm{a}}$ HL-60 and P388 cell lines (each $1 \times 10^{4}$ cells in $100 \mu \mathrm{L}$ ) were treated with test compounds for $72 \mathrm{~h}$, and MTT solution was added to the wells. The grown cells were labeled with $5 \mathrm{mg} / \mathrm{mL}$ MTT in phosphatebuffered saline (PBS), and the absorbance of formazan dissolved with $20 \%$ sodium dodecyl sulfate (SDS) in $0.1 \mathrm{~N} \mathrm{HCl}$ was measured at $550 \mathrm{~nm}$ using a microplate reader. Data are expressed as mean \pm S.D. $(\mathrm{n}=3)$;

${ }^{\mathrm{b}}$ Reference compound.
}

\section{Experimental}

\subsection{General Procedures}

Chemicals and reagents were purchased as follows: fetal bovine serum (FBS) from Invitrogen Co. (Carlsbad, CA, USA), 3-(4,5-dimethyl-2-thiazolyl)-2,5-diphenyl-2H-tetrazolium bromide (MTT) from Sigma-Aldrich Japan Co. (Tokyo, Japan), and 5-fluorouracil (5-FU) (purity $\geq 98.5 \%$ ), arbutin (purity $\geq 95.0 \%$ ), Roswell Park Memorial Institute (RPMI) 1640 medium, Dulbecco's modified Eagle's medium (D-MEM), and antibiotics from Nacalai Tesque, Inc. (Kyoto, Japan). All other chemicals and reagents were of analytical grade. Melting points were determined on a Yanagimoto micro-melting point apparatus and are uncorrected. Optical rotations were measured with a JASCO DIP-1000 digital polarimeter. IR spectra were recorded on a Perkin-Elmer 1720X FTIR spectrophotometer. The ${ }^{1} \mathrm{H}(500 \mathrm{MHz})$ and ${ }^{13} \mathrm{C}(125 \mathrm{MHz}) \mathrm{NMR}$ spectra were recorded on a Varian INOVA 500 spectrometer in $\mathrm{CDCl}_{3}$ with tetramethylsilane as the internal standard. The EIMS was recorded on a Hitachi $4000 \mathrm{H}$ double-focusing mass spectrometer $(70 \mathrm{eV})$. Silica gel (70-230 mesh, Merck) and silica gel 60 (230-400 mesh, Nacalai Tesque, Inc., Kyoto, Japan) were used for column chromatography and medium-pressure liquid chromatography, respectively. The $20 \% \mathrm{AgNO}_{3} / \mathrm{SiO}_{2}$ (w/w) used for chromatography was prepared from silica gel 60 and $\mathrm{AgNO}_{3}$ (Nacalai Tesque, Inc., Kyoto, Japan). HPLC was carried out on an $\mathrm{SiO}_{2}$ column (Cosmosil 5SL-II column, $25 \mathrm{~cm} \times 20 \mathrm{~mm}$ i.d., Nacalai Tesque, Inc., Kyoto, Japan) at $25{ }^{\circ} \mathrm{C}$ with $n$-hexane/EtOAc [10:1 (HPLC system $I$ ) and 5:1 (HPLC system $I I$ ), flow rate $8.0 \mathrm{~mL} / \mathrm{min}]$. 


\subsection{Plant Material}

The seeds of Cucurbita maxima, produced in Japan (Nara prefecture), were purchased from JA (Japan Agricultural Co-operation)-Takatsuki in 2011. A voucher specimen was deposited in the Herbarium of the Laboratory of Medicinal Chemistry, Osaka University of Pharmaceutical Sciences.

\subsection{Extraction and Isolation}

The seeds of Cucurbita maxima $(3 \mathrm{~kg})$ were subjected to extraction with $\mathrm{MeOH}(10 \mathrm{~L})$ under reflux ( 1 week, 4 times). After concentration the $\mathrm{MeOH}$ extract (102.2 g) was then partitioned between $\mathrm{Et}_{2} \mathrm{O}$ and $\mathrm{H}_{2} \mathrm{O}$. The $\mathrm{Et}_{2} \mathrm{O}$-soluble fraction (62.2 g) was subjected to $\mathrm{SiO}_{2}$ column chromatography (CC) $\left[\mathrm{SiO}_{2}(1.5 \mathrm{~kg}) ; \mathrm{CHCl}_{3} / \mathrm{EtOAc}\right.$ 1:0, 5:1, 2:1, 0:1 and $\mathrm{MeOH}$, in increasing order of polarity] resulting in seven fractions (Fr. A-G). Fr. B, eluted with $\mathrm{CHCl}_{3}$, was subjected to $\mathrm{SiO}_{2} \mathrm{CC}$ to yield 10 fractions, B1-B10. Among them, Fr. B3, eluted with hexane/EtOAc (5:1), was subjected to $\mathrm{SiO}_{2} \mathrm{CC}$ to yield 11 fractions; B3-1-B3-11. Preparative HPLC of B3-4 (123.0 mg), eluted with hexane/EtOAc (5:1), gave 4 (15.5 mg; $\mathrm{t}_{\mathrm{R}} 11.2 \mathrm{~min}$ ) (HPLC system I). Fr. C, eluted with $\mathrm{CHCl}_{3}$, was subjected to $\mathrm{SiO}_{2} \mathrm{CC}$ to yield 22 fractions, C1-C22. Preparative HPLC of C3 (14.8 mg), eluted with hexane/EtOAc (10:1), gave $4(5.1 \mathrm{mg})$ and $6\left(3.1 \mathrm{mg} ; \mathrm{t}_{\mathrm{R}} 12.0 \mathrm{~min}\right)$, respectively (HPLC system $\left.I\right)$. Fr. C11 (1.3 g), eluted with hexane/EtOAc (10:1), was subjected to $\mathrm{CC}$ with $20 \% \mathrm{AgNO}_{3} / \mathrm{SiO}_{2}$ to give $\mathrm{C} 11-1-\mathrm{C} 11-11$, followed by $\mathrm{CC}$ of C11-4 (795.6 mg), eluted with hexane/CHCl 3 (20:1), with $20 \% \mathrm{AgNO}_{3} / \mathrm{SiO}_{2}$ to yield C11-4-1-C11-4-9. Preparative HPLC of C11-4-3 (15.0 mg), eluted with hexane/EtOAc (2:1), gave 2 (2.0 mg; $\mathrm{t}_{\mathrm{R}} 18.9 \mathrm{~min}$ ) (HPLC system $\left.I I\right)$. Fr. D, eluted with $\mathrm{CHCl}_{3}$, was fractionated with $\mathrm{SiO}_{2}$ CC to D1-D16. Fr. D4 (1369.0 mg), eluted with hexane/EtOAc (5:1) was subjected to $\mathrm{SiO}_{2} \mathrm{CC}$ to yield D4-1-D4-12. Preparative HPLC of D4-5 (10.0 mg), eluted with hexane/EtOAc (5:1), gave 1 (1.6 mg; $\mathrm{t}_{\mathrm{R}} 15.3 \mathrm{~min}$ ) (HPLC system $\left.I I\right)$. Fr. D4-7 (194.3 mg), eluted with hexane/EtOAc (5:1), was subjected to $\mathrm{SiO}_{2} \mathrm{CC}$ to yield D4-7-1-D4-7-7, followed by preparative HPLC of D4-7-2 (99.9 mg), eluted with hexane/EtOAc (5:1), for the isolation of $2\left(3.0 \mathrm{mg} ; \mathrm{t}_{\mathrm{R}} 22.2 \mathrm{~min}\right)$ and 1 (1.4 mg) (HPLC system II). Fr. D6 (265.4 mg), eluted with hexane/EtOAc (5:1) was subjected to $\mathrm{SiO}_{2}$ CC to yield D6-1-D6-11, followed by preparative HPLC of D6-2 $(6.7 \mathrm{mg})$, eluted with hexane/EtOAc (10:1), for the isolation of 5 (3.6 mg; $\mathrm{t}_{\mathrm{R}} 35.6 \mathrm{~min}$ ) (HPLC system I). Fr. D7 (176.3 mg), eluted with hexane/EtOAc (10:1), was subjected to $\mathrm{SiO}_{2} \mathrm{CC}$ with hexane/EtOAc (10:1) for fractionation to D7-1-D7-12. $\mathrm{SiO}_{2}$ CC of D7-8 gave 3 (1.7 mg).

7 $\alpha$-Methoxymultiflor-8-ene-3 $\alpha, 29$-diol 3-acetate-29-benzoate (1). Amorphous solid; $[\alpha]_{D}^{22}-74.8$ (c 0.1, $\mathrm{CHCl}_{3}$ ); UV (EtOH) $\lambda_{\max }(\log \varepsilon) 206.0$ (3.58), 228.5 (3.68), 271 (2.81) nm; IR (KBr) $v_{\max }$ : 2,924, 2,855, 1,743, 1,724, 1,467, 1,452, 1,374, 1,267, 1,247, 1,110, 1,072 $\mathrm{cm}^{-1} ;{ }^{1} \mathrm{H}-$ and ${ }^{13} \mathrm{C}-\mathrm{NMR}$ spectroscopic data (in ppm), see Table 1; EIMS m/z $618[\mathrm{M}]^{+}(10), 586$ (26), 526 (30), 511 (100), 483 (9), 389 (13), 105 (66); HREIMS $m / z 618.4282$ (calcd for $\mathrm{C}_{40} \mathrm{H}_{58} \mathrm{O}_{5}, 618.4285$ ).

7-Oxomultiflor-8-ene-3 $\alpha, 29$-diol 3-acetate-29-benzoate (2). Amorphous solid; $[\alpha]_{D}^{22}-67.4$ (c 0.1, $\mathrm{CHCl}_{3}$ ); UV (EtOH) $\lambda_{\max }(\log \varepsilon) 233.0$ (3.91), 250.5 (3.81) nm; IR (KBr) v $v_{\max }: 2,937,2,883,1,739$, $1,723,1,658,1,270,1,245 \mathrm{~cm}^{-1} ;{ }^{1} \mathrm{H}$ - and ${ }^{13} \mathrm{C}-\mathrm{NMR}$ spectroscopic data (in ppm), see Table 1; EIMS 
m/z $602[\mathrm{M}]^{+}$(100), 587 (11), 542 (8), 480 (14), 465 (16), 420 (7), 371 (4), 325 (10), 303 (11), 278 (47), 243 (33), 203 (34), 105 (39); HREIMS m/z 602.3975 (calcd for $\mathrm{C}_{39} \mathrm{H}_{54} \mathrm{O}_{5}, 602.3972$ ).

Multiflora-7,9(11)-diene-3 $\alpha, 29-d i o l$ 3-p-hydroxybenzoate-29-benzoate (3). Amorphous solid; $[\alpha]_{D}^{22}$ -3.9 (c 0.09, $\mathrm{CHCl}_{3}$ ); UV (EtOH) $\lambda_{\max }(\log \varepsilon) 231.0$ (4.25), 246.5 (4.12), 266.5 (3.95) nm; IR (KBr) $v_{\max }: 3,436,2,941,2,863,1,716,1,683,1,636,1,509,1,456,1,384,1,274,1,166,1,111 \mathrm{~cm}^{-1} ;{ }^{1} \mathrm{H}-$ and ${ }^{13} \mathrm{C}-\mathrm{NMR}$ spectroscopic data (in ppm), see Table 1; EIMS m/z 664 (16) $[\mathrm{M}]+, 526$ (90) $\left[\mathrm{M}-\mathrm{C}_{7} \mathrm{H}_{6} \mathrm{O}_{3}\right]+$, 511 (32), 389 (26), 253 (41), 121 (100); HREIMS m/z 664.4127 (calcd for $\mathrm{C}_{44} \mathrm{H}_{56} \mathrm{O}_{5}, 664.4127$ ).

\subsection{Cell Cultures}

The cell lines HL-60 (human leukemia) and P388 (murine leukemia) were grown in RPMI 1640 medium, while B16 4A5 cells were grown in D-MEM. The medium was supplemented with 10\% FBS and antibiotics (100 units/mL penicillin and $100 \mu \mathrm{g} / \mathrm{mL}$ streptomycin). The cells were incubated at $37{ }^{\circ} \mathrm{C}$ in a $5 \% \mathrm{CO}_{2}$ humidified incubator.

\subsection{Determination of B16 4A5 Cells Proliferation}

B16 4A5 cell proliferation was examined according to a method reported previously [11] with slight modifications. Briefly, B16 4A5 cells (obtained from the Riken Cell Bank, Tsukuba, Ibaraki, Japan) $\left(3 \times 10^{4}\right.$ cells in $\left.500 \mu \mathrm{L}\right)$, preincubated for $24 \mathrm{~h}$ were treated for $48 \mathrm{~h}$ with test samples dissolved in dimethyl sulfoxide (DMSO) at a final concentration of 100,30 , or $10 \mu \mathrm{M}$, and MTT solution was added. After $3 \mathrm{~h}$ of incubation, 2-propanol containing $0.08 \mathrm{M} \mathrm{HCl}$ was added to dissolve the formazan produced in the cells. The absorbance of each well was read at $550 \mathrm{~nm}$ using a microplate reader.

\subsection{Assay of Melanin Content}

The assay of melanin content was performed as described previously [11] with small modifications. B16 4A5 cells $\left(3 \times 10^{4}\right.$ cells in $\left.500 \mu \mathrm{L}\right)$ were pre-incubated as above in $\alpha$-MSH $(100 \mathrm{nM})$-containing medium. Test samples dissolved in DMSO were added to the medium and the cells were cultured for $48 \mathrm{~h}$. The medium was removed and the cells were dissolved in $2 \mathrm{M} \mathrm{NaOH}$ containing $10 \% \mathrm{DMSO}$. The amount of melanin was determined spectrophotometrically by measuring absorbance at $450 \mathrm{~nm}$ using a microplate reader. The optical density of control cells was assumed to be $100 \%$.

\subsection{Cytotoxicity Assay against Cancer Cell Lines}

The cytotoxicity assay against HL-60 and P388 cells was determined as described previously [12].

\section{Conclusions}

Six multiflorane-type triterpenes, including the three new compounds $7 \alpha$-methoxymultiflor-8-ene3a,29-diol 3-acetate-29-benzoate (1), 7-oxomultiflor-8-ene-3 $\alpha, 29$-diol 3-acetate-29-benzoate (2) and multiflora-7,9(11)-diene-3 $\alpha, 29$-diol 3-p-hydroxybenzoate-29-benzoate (3) were isolated from the $\mathrm{MeOH}$ extract of Cucurbita maxima seeds. The seeds included more 4 than other multiflorane-type 
triterpenes. It was suggested that multiflorane-type triterpenes in C. maxima were biosynthesized from $\mathbf{4}$, or consumed to biosynthesize $\mathbf{4}$. The melanogenesis inhibitory activity of $\mathbf{5}$ suggests they may be potential skin whitening agents. On the other hand, the results of cytotoxicity assays suggest that 2 may be valuable as an anticancer lead compound.

\section{Supplementary Materials}

Supplementary materials can be accessed at: http://www.mdpi.com/1420-3049/18/5/5568/s1.

\section{Acknowledgments}

We thank Katsuhiko Minoura and Mihoyo Fujitake (this university) for NMR and MS measurements.

\section{Conflict of Interest}

The authors declare no conflict of interest.

\section{References}

1. Okada, M., Ed. Newly Revised Illustrated Medicinal Plants of World; Hokuryukan Pablishing Co., Ltd.: Tokyo, Japan, 2002; p. 514.

2. Andrew Chevallier. The Encyclopedia of Medicinal Plants; Seibundo Shinkosha Pablishing Co., Ltd.: Tokyo, Japan, 2000; p. 194.

3. Akihisa, T.; Ghosh, P.; Thakur, S.; Rosenstein, F.U.; Tamura, T.; Matsumoto, T. Widespread occurrence of cucurbita-5,24-dienol in Cucurbitaceae. Yukagaku 1986, 35, 1036-1040.

4. Cattel, L.; Balliano, G.; Caputo, O. Sterols and triterpenes from Cucurbita maxima. Planta Med. 1979, 37, 264-267.

5. Fenner, G.P.; Patterson, G.W.; Koines, P.M. Sterol composition during the life cycle of the soybean and the squash. Lipids 1986, 21, 48-51.

6. Fenner, G.P.; Patterson, G.W.; Lusby, W.R. Developmental regulation of sterol biosynthesis in Cucurbita maxima L. Lipids 1989, 24, 271-277.

7. Ukiya, M.; Akihisa, T.; Tokuda, H.; Toriumi, M.; Mukainaka, T.; Banno, N.; Kimura, Y.; Hasegawa, J.; Nishino, H. Inhibitory Effects of Cucurbitane Glycosides and Other Triterpenoids from the Fruit of Momordica grosvenori on Epstein-Barr Virus Early Antigen Induced by Tumor Promoter 12-O-Tetradecanoylphorbol-13-acetate. J. Agric. Food Chem. 2002, 50, 6710-6715.

8. Sekine, T.; Kurihara, H.; Waku, M.; Ikegami, F.; Ruangrungsi, N. A New Pentacyclic Cucurbitane Glucoside and a New Triterpene from the Fruits of Gymnopetalum integrifolium. Chem. Pharm. Bull. 2002, 50, 645-648.

9. Akihisa, T.; Tamura, T.; Matsumoto, T.; Eggleston, D.S.; Kokke, W.C.M.C. Karounidiol [D:C-friedo-oleana-7,9(11)-diene-3 $\alpha, 29$-diol] and its 3-O-benzoate: novel pentacyclic triterpenes from Trichosanthes kirilowii. X-ray molecular structure of karounidiol diacetate. J. Chem. Soc. Perkin Trans. I 1988, 3, 439-443. 
10. Lim, Y.-J.; Lee, E.H.; Kang, T.H.; Ha, S.K.; Oh, M.S.; Kim, S.M.; Yoon, T.-J.; Kang, C.; Park, J.-H.; Kim, S.Y. Inhibitory effects of arbutin on melanin biosynthesis of $\alpha$-melanocyte stimulating hormone-induced hyperpigmentation in cultured Brownish guinea pig skin tissues. Arch. Pharm. Res. 2009, 32, 367-373.

11. Akihisa, T.; Seino, K.; Kaneko, E.; Watanabe, K.; Tochizawa, S.; Fukatsu, M.; Banno, N.; Metori, K.; Kimura, Y. Melanogenesis inhibitory activities of iridoid-, hemiterpene-, and fatty acid-glycosides from the fruits of Morinda citrifolia (Noni). J. Oleo Sci. 2010, 59, 49-57.

12. Yamada, T.; Muroga, Y.; Jinno, M.; Kajimoto, T.; Usami, Y.; Numata, A.; Tanaka, R. New class azaphilone produced by a marine fish-derived Chaetomium globosum. The stereochemistry and biological activities. Bioorg. Med. Chem. 2011, 19, 4106-4113.

Sample Availability: Not available.

(C) 2013 by the authors; licensee MDPI, Basel, Switzerland. This article is an open access article distributed under the terms and conditions of the Creative Commons Attribution license (http://creativecommons.org/licenses/by/3.0/). 